\title{
Modernity Contextualises New Zealand's Royal Commission on Genetic Modification: A Discourse Analysis
}

\author{
TEE ROGERS-HAYDEN \\ University of Waikato \\ RICHARD HINDMARSH \\ University of Queensland
}

On 30 July 2001, the four-volume 1200 page report of New Zealand's Royal Commission on Genetic Modification (RCGM) was released. This was timely for the government; it was soon to legislate on its expiring one-year voluntary moratorium on the environmental releases of genetically modified organisms (GMOs), both for field trials and commercial applications. Despite strong public opposition to genetic engineering (GE), the RCGM findings tended to support the ongoing development of GE in Aotearoa/New Zealand, ${ }^{1}$ and recommended the recommencement of GM field trials and planning for GMO releases.

The findings met with mixed reactions. Some proponents of biotechnology, such as Brian Arnst, the public relations manager for Monsanto NZ, suggested that they were as expected. ${ }^{2}$ Others from a diverse range of public interest groups were surprised, and, like the majority of New Zealanders, disappointed. Soon after the report's release, one of the largest marches against genetic engineering in western countries to date occurred in Auckland. The estimated 10,000 strong 'Keep New Zealand GE Free' rally was awash with costumes, placards and metaphors, such as 'Proud to be GE free', 'Tomatoes not Frog-atoes!', 'Say NO to Pigato', '\$top Life Patents - You are Next!', 'Progress at What Cost? - Is this to be the Last GE-free Spring Ever?', 'Do something to STOP GM Madness!'3

Those placards signalled some of the pertinent issues associated with genetic engineering. They include, but are not restricted to: release into the environment of GE organisms; the safety of GM foods; consumer choice and right to know; the private ownership of genetic material through 
intellectual property rights; the subsequent convergence of public and private research; increasing control of agri-food production and seed ownership by agribusiness and biotech conglomerates; the very desirability of genetic engineering vis-à-vis other modes of production; the 'biocolonisation' of nature to align it to a techno-industrial milieu; or, the bioprospecting of indigenous knowledge. ${ }^{4}$

Compounding public consternation was that the controversial RCGM findings had closely followed a Tasmanian parliamentary select committee's findings on GM. The Tasmanian recommendations contrasted with those of the RCGM; they supported a continuation of the Tasmanian GM crop release moratorium, and also expressed a strong desire to declare Tasmania GM-free. One reason was a desire to position Tasmania favourably for emergent global markets demanding 'GM-free' produce. Similarly, many environmental, Maori, religious, health and organic orientated groups had expressed such preferences to the RCGM for Aotearoa/New Zealand's future. $^{5}$

Consequently, many Aotearoa/New Zealand environmental groups perceived the RCGM findings to be advocating for genetic engineering. Green Party co-leader Jeanette Fitzsimons stated, ‘. . . we just couldn't see how they [the RCGM] could come to those conclusions on the basis of what they heard'. ${ }^{6}$ Prior to the findings, many had been confident that the Royal Commission would result in a continued moratorium on GMO releases. Greenpeace New Zealand's GE campaigner Annette Cotter stated, . . . because of the strong public opposition and that kind of thing, the Commission is very unlikely to come up with a policy that says go for it'?

Numerous public demonstrations, GM-free zones declared across the country, and public opinion polls tended to support the optimistic biocritics' pronouncements. This was further evidenced by the high number of public submissions to the RCGM, either strongly against, or tending to be against, GM (9,998 - 92\% - of the 10,861 submissions). By way of contrast, a recent and highly publicised Australian Senate inquiry into genetic engineering attracted only 109 submissions, of which about 40 were from the public. ${ }^{8}$ Perhaps a reason for the difference in the number of submissions to each inquiry is a perception that Royal Commissions are independent inquiries, whereas parliamentary inquiries are overtly conducted by politicians. ${ }^{9}$ More pointedly, the many submissions to the RCGM represented a significant mobilisation of public protest in New Zealand. Indeed, apart from mass mobilisations of Asian peasant movements against genetic engineering, ${ }^{10}$ in the western world the New Zealand mobilisation appears to have been eclipsed only by the degree of activism in the vigorous United Kingdom campaign. ${ }^{11}$ Yet, despite the strong public opposition in Aotearoa/New 
Zealand, the RCGM made clear its intent to ignore it: 'We wish to stress ... that the terms of reference did not direct us to conduct our enquiry as if it were a referendum'. ${ }^{12}$

There was already a precedent across the Tasman in setting terms of reference to nullify public opposition to GE. Australia's first inquiry into genetic engineering was convened by the Federal Government's House of Representatives in 1992. In that instance the terms of reference (set by the Minister for Industry, Science and Technology) included an a priori and unqualified acceptance of the benefits of recombinant-DNA work. This effectively placed any opposition to genetic engineering, whether expressed in submissions or at hearings, outside the boundaries of the inquiry. Subsequently, although $35 \%$ of the submissions (those from the public) advocated an immediate halt to GE work in Australia, this public preference went unreported when the inquiry's findings were tabled. ${ }^{13}$

This case illustrates how inquiries can act as forms of power/knowledge to confine or defuse debates. ${ }^{14}$ Ashforth advances three reasons why inquiries, such as those into genetic engineering in Aotearoa/New Zealand and Australia, are held, and why they can arrive at outcomes contradictory to well-stated public preferences. They may be conducted: firstly, to appease the discontent of public interest groups with the power to destabilise industrial development programmes supported by the state; secondly, to address the limitation of resources within the bureaucracy to face a pressing and complex problem; thirdly, to maximise gains for key interests. Here, the last would refer to genetic engineering interests. ${ }^{15}$

It has also been suggested that such inquiries may represent '.. a system of intellectual collusion whereby selected . . intelligentsia transmit forms of knowledge into political practices. The effect of this process is to replenish official arguments with both established and novel modes of knowing and forms of reasoning. ${ }^{16}$ For example, the Australian House of Representatives inquiry's report - Genetic Manipulation: The Threat or the Glory? - was used effectively for some time by bioproponents as a 'persuasive' text to popularise genetic engineering as an 'inevitable' and highly desirable social and natural 'reality'. This served to strengthen the bioscientific discourse as dominant vis-à-vis the discourse of biocritics, especially environmentalists. ${ }^{17}$ Likewise, in Aotearoa/New Zealand, bioproponents have begun to position the RCGM report as a legitimising text for the future. In the words of Business New Zealand's chief executive Simon Carlaw: 'The Royal Commission . . . appears to have taken a cautious step that offers the prospect of a sensible way forward'. ${ }^{18}$ Similarly, Federated Farmers of New Zealand (Inc) President, Alistair Polson, indicated: 'We agree with the Royal Commission's conclusion that it would be unwise to turn our backs on the potential advantages on offer but we must proceed 
carefully, minimising and managing risks'. ${ }^{19}$ This intimation by business and conventional farmers of support for 'going forward with GE' ignored that the Commission's report was not legally binding, and that its findings faced widespread public dissent.

In this paper, we explore the negotiation of the RCGM process and its implied advocacy for GE against the background of public disapproval for GM, especially that of environmentalists. Our interest in the latter arises from our position in the debate, defined as a position of the third space of critical engagement. ${ }^{20}$ In short, we adopt an environmental public-interest stance and straddle the so-called academic-activist divide. ${ }^{21}$ A key aim is to investigate some of the constraints placed on environmentalist groups when they attempted to voice their objection to GE through the RCGM. A relevant observation that informs our view is that of Arne Naess: 'In environmental conflicts, it is . . important to map out the power structures relevant in pushing the decisions and determining the different stages in [environmental] conflict'.22 Obviously, such analysis is needed in order to understand, and to participate effectively in, the policy process.

To introduce our subject, we background the composition and terms of reference of the Royal Commission. We then deconstruct (or unpack) the RCGM as a multidimensional discourse involving the development and role of established and novel modes of knowing and forms of reasoning. An integral part of this is exploration of the intersection of the Commission's gathering and analysis of the submissions, as well as some of its key findings relevant to environmentalists.

\section{Background}

Parallel to the intense and escalating international debate about genetic engineering over the last decade, the public of Aotearoa/New Zealand also demonstrated its wariness of the hype surrounding a GM future. In 1990, a comprehensive survey undertaken by New Zealand's Department of Scientific and Industrial Research found that $56 \%$ of the public had concerns about the applications of genetic engineering. ${ }^{23}$ Since then, with environmental, consumer, Maori and other public interest groups more actively engaged with the debate, and with substantially more media coverage, public concerns over GE have grown. So much so, that genetic engineering became a 'hot' issue in the 1999 national elections, with the Green Party calling for a Royal Commission in its electoral campaign. The Royal Commission on Genetic Modification was eventually established by the Labour-Alliance coalition government, and was constituted on 8 May 2000.

The appointed members of the Royal Commission were the Right Honourable Sir Thomas Eichelbaum (Chief Justice of New Zealand from 
1989 to 1999); Jacqueline Allen (a general practitioner in South Auckland with community and Maori health expertise); Dr Jean Fleming (a biochemist and molecular reproduction and endocrinology researcher); and the Right Reverend Richard Randerson (Bishop of the Anglican Church). ${ }^{24}$ The Commission was given just over a year, later extended by two months (until 27 July 2001), to report its recommendations to the government.

The terms of the Commission's warrant were: '. . . to receive representations upon, inquire into, investigate, and report upon the following matters:

1. the strategic options available to enable New Zealand to address, now and in the future, genetic modification, genetically modified organisms, and products; and

2. any changes considered desirable to the current legislative, regulatory, policy, or institutional arrangements for addressing, in New Zealand, genetic modification, genetically modified organisms, and products. ${ }^{25}$

The Commission's investigation was to be based on evidence gathered from public meetings, written submissions from the public, hui with Maori (meetings with the indigenous peoples), and from written and oral submissions from groups deemed 'interested persons' (IP). To gain IP status a group must have proved that it had an '.. . an interest in the Inquiry apart from any interest in common with the public'. ${ }^{26}$

\section{The Theoretical Context}

Many environmental discourses exist today - such as those of deep ecology, social ecology, eco-feminism, or eco-technological transformation - that argue that industrial society is now engaged in a crisis of perception with regard to society-technology-nature relationships. Some, like Fritjof Capra - who follows in the Romantic tradition and suggests a deep ecology science - assert we are already in a period of paradigm shift from dry to deep green values. ${ }^{27}$ Although these views inform our position, and also informed many of the environmentalist submissions to the RCGM, for our critical approach of discourse analysis (which we discuss later) Ulrich Beck's concept of a risk society provides a useful frame of reference. ${ }^{28}$

Beck's analysis of environmental conflicts is relevant to contemporary societal transition and fluidly embraces the controversy over genetic modification and the consequential RCGM. Beck conceptualises three periods of societal transition: modernity; second modernity and reflexive modernisation (risk society). Modernity relates to the period of industrialisation. Second modernity, the phase we are currently in, forms the transitional stage between industrial society and reflexive modernity. The last is an alternative modernity - an 'ideal type' future - in which 
society comprehensively and proactively reflects and addresses the processes, ideals, and failings, of modernity.

The contemporary importance of these phases relates to a shift of focus from industrial society's preoccupation with the production of material goods to a parallel focus on the production or generation of risks. The current transitional period to risk society is one where the ideologies and practices of modernity - for example, progress, economic growth, and western science and technology - are under intense paradigmatic challenge for their perceived role in escalating environmental and social problems, and for not having adequate critical facilities to address them. ${ }^{29}$ In this contested terrain, genetic engineering has become a perceived megatechnological risk. Indeed, the scope of issues and protests surrounding GM exemplifies the upheaval found in the transitional period between modernity and reflexive modernisation.

In seeking open public debate, a public inquiry would appear to offer not only an opportunity to explore contentious issues but also a forum to reflect upon the processes that give rise to them. Critical reflection upon the processes of modernity and their use in risk society is, to reiterate, a key element of moving into reflexive modernity. Without willing, adequate and open consideration of the failures of modernist ideals and practices, attempts to effectively address new, second modernity, globe-threatening risks will in all likelihood be rendered impotent.

Discourse analysis offers a key way to explore and reflect upon the negotiation of the GE debate through the RCGM - both a policy process, and a text shaping the future process of policy. A useful definition of 'discourse' is: 'a framework that includes whole sets of ideas, words, concepts, and practices. Discourses are the general context in which ideas take on a specific meaning and inform particular practices. A discourse is a set of widely held ideas that a society relies on to make sense of the world, a set of general beliefs about the nature of reality. ${ }^{30}$

The use of discourse analysis allows us to analyse language and its structure to investigate social power relations. The application of Fairclough's multi-dimensional discourse analysis model supports the notion of modernist ideals constituting a central element of the RCGM discourse. ${ }^{31}$ Fairclough views discourse as comprising three concurrent elements: the social context; the discursive field; and the text. The first of these is the social context, in which hegemonic (dominant and 'naturalised') power relations are contested. Within this paper we are exploring the hegemony of modernist ideals as the social context of the RCGM. Within the social context lies the discursive practice where the production and distribution of information is analysed. This element here consists of the ways in which the RCGM gathered and analysed the submissions, which arguably 
'coloured' its report. Finally, in the third element of Fairclough's model lies the text, which in the case of the RCGM we have nominated as its findings. These findings are deconstructed to form the final constitutive part of our discourse analysis of the RCGM.

Hegemony describes unequal power relations that reside in unstable but constant conditions of equilibrium built on the subordination of groups and classes. The latter continuously struggle against dominant actors who are positioned best to shape society and its technological base and form. ${ }^{32}$ Thus, the negotiation over genetic engineering is comprised of a complex struggle of competing as well as contiguous or shared interests found in contesting policy networks and communities. At any one time and in any particular domain - such as the RCGM - complementary and contradictory linkages of power (for example, reproduction of domination, resistance, challenge, transformation) are engaged, dependent on the nature and success of competitive power strategies. From such engagement of social power, as currently found over genetic engineering in Aotearoa/New Zealand (and elsewhere), the technological trajectories and modes of production for the future are shaped. The practices of argument - discursive practices - form a central mode of influence in this engagement and contestation.

When contestation continues, hegemony can never be complete, and resistance and transformational discourses that challenge hegemonic discourses have a capability to undermine and/or to 'open up' entrenched power structures, and thus to delegitimise and disempower them. In response, actors operating from domains of structural (or dominant organisational) power embellish existing strategies of hegemony. As Bruno Latour said, 'Technoscience is war . . Its object is domination and its methods involve the mobilization of allies, their multiplication and their drilling, their strategic and forceful juxtaposition to the enemy. ${ }^{33}$ A central strategic ploy found in contestations over technoscience, such as genetic engineering, is where dominant actors strive to control rules of passage in the terrain. ${ }^{34}$ In this context, the RCGM undergoes a shift from its literal representation as a democratic and independent avenue of public inquiry to representation as a conduit of power that requires certain rules of passage. This latter representation is the object of our analysis. Specifically, we are exploring the discourse and discursive practices of the RCGM as frameworks of power, which set and controlled rules of passage that advantaged some and disadvantaged others.

\section{The Social Context}

The European scientific revolution of the fifteenth to seventeenth centuries, culminating in the Enlightenment closely followed by the industrial revolution, ushered in modernity. ${ }^{35}$ A key element of modernity was the 
transformation of structures of knowledge. Reliance on tradition (religion) and organicism as the foundation of knowledge was replaced by a new dependence on rationality, 'objectivity', and an 'atomistic' portrayal of reality, in which humans were repositioned as 'context-independent' 'masters' of nature. The new worldview was underpinned by a belief in unlimited progress facilitated by modern science and technology. This viewpoint, expounded especially by thinkers such as Bacon, Descartes and Newton, saw nature as a 'machine', the parts of which could be manipulated and exploited for human benefit. ${ }^{36}$ Genetic engineering represents a sublime contemporary expression of this view. 'Genes' are 'decoded' as 'parts of the DNA alphabet', or as 'bits of information' that can be 'reshuffled' or 'restacked' in the new genomic 'book of life'. In short, the secular and mechanistic cosmology of Enlightenment science, and its quantitative method and laboratory tools, such as the microscope, 'abstracted, reduced and organised' nature's complexity into various atomistic functions or aspects according to universalistic mathematical laws and relations. Science became the key to 'subduing and controlling' nature for collective human purpose.

At the same time, the holistic worldview of a 'living nature' that deserved a responsible and caring human relationship became oppressed. Likewise, the early nature movement, coined as the Romantic movement, which emerged in the late eighteenth century to advocate the concepts of spiritual unity with nature and organism (later known as vitalism) and which rejected rationalism and reductionism, ${ }^{37}$ became marginalised.

It was not until nearly two centuries later, in the 1960s and 1970s, that a more powerful nature movement emerged to contest modernist principles. The realist narrative (positivism) that modern science is the one truth to understanding, and the basis of relating to, nature became particularly contested by the emergence of the social responsibility of science movement, the radical environmental movement, and more recently by postmodernist and feminist scholars.

In contesting modernity, these critiques perceive rationality as embedded within culture, and conversely, that rationality shapes culture. ${ }^{38}$ Restivo, amongst others, relates how the scientific revolution - based on the oppression of women, minorities and labourers, and the exploitation of human and nonhuman 'resources' - developed from social and cultural circumstances. ${ }^{39}$ Knowledge was intimately related to power structures found in politics, commerce, and the military, as it still is today. The scientific revolution was not just an intellectual revolution but also an organisational and institutional revolution; a point Restivo believes is not widely understood. Harding describes the relationship between knowledge and institutional power as the 'order of society'. ${ }^{40}$ These notions help 
contextualise the centrality of modernity to any critical discussion of the RCGM. Modernist principles that form the implicit assumptions of what appears as 'natural' and 'given' have been widely disseminated and adopted in our society, and thus can be considered hegemonic. Other ways of knowing have been marginalised, and continue to be marginalised, through many forms of power/knowledge relations that shape public discourse about our relationship to nature. ${ }^{41}$ A central example is the notion of 'sustainable development'; a concept that Coutinho argues has as a central intent, the 'disqualification of catastrophist or otherwise radical discourses on the relation between society and the environment'. ${ }^{42}$

Environmental groups, in contesting the genetic engineering debate through the RCGM, were thus contesting, implicitly or explicitly, assumptions of modernity. Cozzens and Woodhouse suggest that within the broader texture of the environmental movement many would be unaware that their contestation of GM could be considered as epistemological and/or ontological. ${ }^{43}$ Yet, many environmental groups may progress from addressing the particular issues that triggered their environmental concern to epistemological and/or ontological concerns. For example, those who began campaigning on visible pollution may also develop a critique of systems of knowledge when their experiences of visible pollution are discounted in favour of contradicting 'scientific evidence'. Likewise, in campaigning against genetic engineering those who began by expressing a moral aversion to tampering with the genetic 'code' may, upon being challenged by scientific objection, turn their attention to examining the underlying scientific worldview in more detail. ${ }^{44}$ Degrees of awareness thus vary so that environmental and/or social critiques may also be critiques of modernity. This is especially the case among those categorised as 'light greens', 'reform greens', or 'shallow greens'. By way of contrast, 'deep greens' or radical environmentalists, the women's health movement, and the alternative health movement, possess more sophisticated critiques of knowledge/power, and are thus more explicit in their critiques of hegemony and modernist discourses.

In addition to modernist principles manifesting themselves as hegemonic through the establishment of modernist knowledge systems, hegemony is also found in the privileging of modernist forms of reasoning. For example, with the Cartesian separation of the 'rational' from other forms of reasoning during the scientific revolution, ${ }^{45}$ science became entrenched as the discourse of public life in official and governmental texts. With the scientific dominating, romantic discourses became delegated to the 'private' sphere as inferior forms of reasoning unsuitable for public decision-making.

Thus, in addressing hegemonic knowledge systems, environmental groups are often confronted with the rational (public): romantic (private) discourse 
split brought about by modernity. Environmental problems are thus usually framed as 'objective' problems, best addressed by 'rational' or 'sound' science. Although it is accepted that some environmental issues have only become apparent through science (such as the 'hole' in the ozone layer), a narrow reliance on science acts to distort perceptions of environmental problems as being unconnected to each other, and also from social and economic conditions. Inadequate solutions most often result. ${ }^{46}$ Social and cultural concerns become marginalised, including those about ethics, ecosocial justice and alternative societal futures. Public attention is shifted away from the contestation of dominant discourses. ${ }^{47}$ Such rationalisation of debate on environmental issues, Grove-White suggests ${ }^{48}$ serves the interests of governments keen to enframe debate in politically 'neutral' terms, which, in turn, acts to 'absorb' dissent.

With regard to genetic engineering, debate rationalisation has been proactively crafted internationally, especially through forums in the United Kingdom and United States. ${ }^{49}$ With regard to the containment of open debate in Australia, Hindmarsh identified that process as the 'mobilisation of bias'. ${ }^{50}$ Containment of debate, Loge asserts, is a central strategy of the discourse of biotechnology or 'biospeak', as he has nominated it. ${ }^{51}$ Two 'grammars' comprise biospeak: 'technologised' and 'mythologised'. 'Technologised' refers to the 'protected' language or jargon of technoscience, which acts to exclude the public through technoscience illiteracy and reinforce the socially insulated position of the techno-elite. As a strategy of technicalisation its aim is thus to monopolise power through scientific or expert authority. ${ }^{52}$ This is achieved by assigning only 'scientific' or 'technical' meanings to (bio)technology issues. Discussions of the issues are only considered legitimate where they fit 'within the frame of science'. ${ }^{53}$

In this context, it is notable that three of the four Commissioners conducting the RCGM were from a legal or scientific background, including one with a genetic engineering background. The other Commissioner was from the Anglican Church, which adopts primarily an anthropocentric cosmological position largely uncritical of genetic engineering, with some exceptions in the human domain. While this does not prescribe a particular perspective on GE by any of the Commissioners, it does suggest that people from these backgrounds would be predisposed to favour modernist disciplines in epistemology and ontology. Certainly, if environmental positions were held, the Commissioner's backgrounds would suggest only shallow environmental worldviews, are incrementalist and reform-focused and working within modernist principles. In selecting the four Commissioners, the Minister for the Environment, the Hon Marian Hobbs, stated: 'The science and medical community are well represented 
on the Commission'. ${ }^{54}$ It is significant that while the science and medical communities were well represented the environmental community was not.

In turn, the 'mythologised' grammar of biospeak refers to 'the literal application of the metaphor', which strives to enrol 'allies' to a GM futurenatural. For example: 'The living world can now be viewed as a vast Lego kit inviting combination, hybridisation and continual rebuilding, ${ }^{55}$ Nature can be reordered through 'breaking' and 'redesigning' the 'DNA code'. The key to the reordering of nature is 'the gene' cast as 'master molecule'. This also tends to reinforce hierarchical and fractured notions of nature, as well as upholding the model of class capitalism through the portrayal of the gene as higher than the cell or organisms, or as 'factory foreman' in the 'production line of proteins'. ${ }^{56}$ Moral and scientific discourses combine where the gene is also portrayed as 'saviour' to feed the hungry of the world, and as 'the key to controlling our biological destiny' so that we may live longer, free of disease, defects, or imperfection. A central message to critics is that, by delaying such technical progress, society risks failing to develop the necessary technology to achieve a bio-utopia. ${ }^{57}$ To counter GM activists, ecological discourses are appropriated to portray GM foods as 'natural', 'clean, 'green', 'safe', 'environmentally-friendly', and even 'organic'. Such rhetorical devices thus attempt to paint a winning picture of GM. They aim to 'persuade'.

In response, environmental activists contest the terrain in many ways. A popular strategy is the attempt to delegitimise GE in the public domain by also painting metaphorical landscapes of persuasion. Pollution metaphors aim to stigmatise genetic engineering as 'genetic contamination' through gene flow from GM crops to non-GM crops via cross-pollination, ${ }^{58}$ and thus to catalyse public debate about future choices about nature and society, and about food labelling. Another key metaphor employed is 'GM foods as Frankenfoods', which attempts to demonise GM as a 'technological monster out of control', and as 'unaccountable'. Such representation evokes responses from many people with deep ethical and moral concerns about scientific experimentation. Through this approach, biocritics employ romantic arguments about scientific responsibility, as well as about care for nature.

A second popular strategy of contestation is through attempts to harness science to argue environmental issues, and thus to meet agents of modernity 'on their own ground', the 'legitimate' ground. This was the strategy of the peak environmental groups Green Alliance and Greenpeace during the United Kingdom GM debate. It tends to accept the dominant discourse of 'sound science' as pre-eminent in offering the solution for the environmental problems of GM. In turn, this tends to accept the substance and terms of debate as set by the proponents as being pre-eminent within modernist 
technical discourse, for example, biophysical risks (or the degree of safety of releasing GMOs into the environment). ${ }^{59}$ But in accepting scientific reasoning as pre-eminent, these groups uphold the rational/public and romantic/private discourse split, and are, in any case, usually out-manoeuvred in the terrain of contestation.

A lesser-adopted avenue for environmental groups is to attempt to straddle the rational/public: romantic/private discourse split. This was demonstrated in some of the submissions to the RCGM, yet the attempt was hampered by the RCGM's set rules of passage for its process and analysis, as expressed, in the first instance, through the submission template.

\section{The Submission Template}

In submissions to the RCGM, all Interested Persons (IPs) were required to present their arguments within a 16 -question template. ${ }^{60}$ Unlike the normative GM debate rationalisation, the RCGM template invited discussion on the nonphysical aspects of GM as follows: ${ }^{\prime} \mathrm{B}(\mathrm{j})$ the main areas of public interest in genetic modification, genetically modified organisms, and products, including those related to . . . (iv) cultural and ethical concerns'. ${ }^{61}$

Despite the invitation to discuss broader concerns, which extended the rational to include the romantic, the template posed obstacles to actually extending the discourse. This was because the Commission ruled that all answers were to 'stand alone'; in other words, a parts approach was employed, an elemental condition of the epistemology of modernity. In setting this condition the Commission constrained those submitting, denying them the opportunity to contextualise adequately their opposition to, or concerns about, GM within the framework of their worldview.

Noam Chomsky has defined a parallel to this 'concision' in the world of mainstream media interviewing. ${ }^{62}$ This is where interviewees have to fit their answers to interview questions into 'bites', sandwiched between the advertisements. This, Chomsky explains, means that interviewees have to conform to mainstream thought in order to get their message across quickly and 'appropriately' to a mass media audience. Obviously this constrains answers that need contextualisation through perhaps long or complex explanation.

Adequate licence for contextualisation would have enabled environmental groups to better explain the assumptions and values underpinning their submissions, and to thus challenge more effectively the (hegemonic) values and assumptions of the RCGM's social context of modernity. Alternative expressions about GM would then, arguably, have received more consideration in the Commission's deliberations; certainly more equity to express representative opinion within argument would have resulted. The following passage, taken from the executive summary of the Green Party's submission, 
illustrates this point: 'It would not have been our preference to organise our submission in this way ... We have had to put the explanation of our own philosophy under "public interest" because it is the only heading that mentions ethics. ${ }^{63}$

Further difficulty in answering questions, especially when one has an alternative worldview to 'the dominant one,' was explained by Berylla of the Environment Conservation Organisation (ECO): 'I think the way the Commission wanted information formatted into categories made it difficult to make a coherent submission, especially for groups like ECO that were taking an ecosystems approach. We see everything as affecting everything else. We did not want to break down our responses into the categories they had designated ${ }^{64}$ It would appear that environmental groups would have benefited from an alternative to the template, one in which they could have 'built' an argument explaining their worldview before providing contextualised responses to the RCGM's questions.

\section{Design and Process}

Environmental groups concerns about the reductionist methodology of 'stand alone' template answers were subsequently heightened by apprehension that a reductionist approach would also be used for the Commission's analysis of the submissions. Environmentalists were anxious about the possibility that summaries, or generalised compressions, of their responses on each question would be given to the Commissioners to deliberate. If this were done, it would compromise, and thus misrepresent, the diversity of opinions and ecological worldviews held amongst environmental groups.

The process that eventuated, although slightly different to that envisaged by critics, was still compromising, and thus misrepresentational. Although each IP submission was individually summarised, all were collated into an IP report, which was used as a '. . . working document to assist the Commissioners in their deliberations on evidence presented'. ${ }^{65}$ As both a qualitative and quantitative analysis of the submissions: 'The approach adopted for the summary and analysis of submissions by Interested Persons was therefore largely dictated by the format in which the evidence was presented (i.e., the specific Warrant items) and by the perceived requirements of the Commissioners' ${ }^{66}$ The result of this process was to restrict further the desire of some environmental groups to express their opposition to GM within their respective worldviews. This further distorted and compromised environmentalist arguments and perspectives.

\section{Text: Analysing the Findings}

Despite the difficulties that faced the IPs in expressing their specific worldviews within the submission template, the RCGM did include some 
nominal discussion of worldviews in its findings. In the 25 pages devoted to cultural, ethical and spiritual issues the RCGM stated: '. . . [I]t is important to make these world views visible in the debate as they have an important place in shaping the choices made about ethical issues raised by genetic modification. ${ }^{67}$ In a short and inadequate summation, the RCGM discussed Te Ao Maori (the traditional Maori worldview), the ecological worldview, and the Judeo-Christian worldview. But the RCGM neglected to discuss its own operational worldview, the dominant worldview of progress and modern science and technology otherwise known as the 'technocractic metadiscourse', ${ }^{68}$ which has elsewhere been ascribed as the discourse of modernity. Either the RCGM was blinkered to its own biases, or its worldview as the dominant one in western society was seen to be above scrutiny. Instead, the approach of the RCGM was to look only for shared values between the divergent worldviews, including that of the bioproponents (which we have already identified as belonging to modernity). The RCGM stated: '. . . in the midst of such diversity, can a common core of values be found as a basis for ethical decision-making? The Commission debated that question and decided that such a common core of values exists. ${ }^{69}$

The 'core values' approach to environmental management has surfaced in recent years in both Aotearoa/New Zealand and Australia as a way to address conflict among seemingly divergent interests with differing valuepositions, and thus differing ideologies and ethics. Fundamentally, it seeks compromise and represents an incrementalist approach that does not overly challenge the dominant worldview; the 'problem' can be managed within the rule boundaries of rational planning set by 'the system'.70

The RCGM listed seven shared values, one of which was 'sustainability.' ${ }^{71}$ In its literal representation, sustainability appears to offer a shared value, both the bioproponents' and biocritics' submissions citing a dedication to this 'core value'. For example, GM conglomerate Aventis CropScience stated: 'In Aventis, our challenge is life and we are driven by the global needs for food safety, sustainability, and a cleaner environment. When we look to the big picture, we understand that biotechnology and GM foods will play a critical role in feeding the world's population of 9 billion by 2025. ${ }^{72}$ Here, the image of 'sustainability' combines a moral message with a scientific one: that is, of producing food for the hungry through GE. Yet, the same term acquires a different (and arguably, contradictory) meaning in the following passage: 'Aventis CropScience product stewardship activities extend beyond regulatory requirements in our efforts to manage the sustainability of our products in the environment. ${ }^{73}$ This suggests that 'sustainability' means maintaining the market for Aventis GE products. The Judeo-Christian anthropocentric metaphor of 'stewardship' for, or 'wise 
management' of, the biophysical environment is thus extended to Aventis products. The company will even 'extend beyond regulatory requirements' to achieve this goal. An image of 'biotechnology as benefactor of society and environment' is thus portrayed. Such rhetorical use of imagery merges the concept of sustainability with that of the mythologised grammar of biospeak, the biotechnology discourse. ${ }^{74}$

By way of contrast, the environmental group Nelson GE-Free Awareness refuted that bioproponents were valuing sustainability in any meaningful way. From its perspective, ' $[\mathrm{g}]$ enetic engineering is all about experiment and has nothing to do with an effective sustainable future. ${ }^{75}$ Instead, Nelson GE-Free Awareness' view was that: '. . sustainable systems are those promoted by organics, and that these produce food in a safe and environmentally sensitive way which benefits the entire ecosystem.76

Thus, for GE proponents, sustainability means using GE. But, for environmentalists, sustainability is threatened by GE and is instead achieved by organics. It may be unfair to suggest that the RCGM overlooked the different rhetorical landscapes portrayed in these divergent perspectives, but the worldview behind the two views is clearly very different. As the RCGM ambiguously stated, ‘. . there are widespread differences of view on how to give effect to shared view' ${ }^{77}$ Despite this finding, and global consensus about the well-known lack of definitional rigour of the term 'sustainability', ${ }^{78}$ as well as the political intent of marginalising radical environmental thought through the popularisation of the concept ${ }^{79}$ the Commission identified 'sustainability' as a core value. Perhaps the Commissioners were not well versed in the field of environmental politics. Again this would highlight the absence of adequate representation for the environmental community in the RCGM.

The set of core values is essential to the GM decision-making framework of the proposed Bioethics Council. As the RCGM stated: 'In the absence of an effective framework for ethical decision making, decisions about the use of biotechnology will be made by default. It is vital that the Bioethics Council provide continuing consultation and active choice, allowing developments in biotechnology to be based on the values we hold in common. ${ }^{90}$ In other words, without 'an effective framework for ethical decision making', decisions will likely be made according to the status quo. However, if values in common can be negotiated successfully, the Council can develop GE according to these values. The apparent emphasis is that GE should develop; it is just a matter of achieving the right balance of values and ethics, deliberated upon by a 'governing' Bioethics Council.

Thus, the overall effect of adopting a core values process to determine assessment procedures for GE to develop not only presupposed support for GE (which was in direct contradiction to the clear opposition to GE by the 
vast majority of submissions), but also clearly and effectively sidestepped the central issue of power (structures of knowing and meaning) inherent within clearly contesting worldviews. In doing this, and in not simultaneously reflecting upon and addressing the established modes of knowing and reasoning of the modernist worldview, within which it was defined, the effect of the RCGM was to silence much of the substance of environmentalist arguments about genetic engineering. In short, the outcome was that the RCGM affected an empowering conduit to genetic engineering interests, and a disempowering one to those who contested GE.

In its submission to the RCGM, Friends of the Earth (FoE) had actually expressed a fear of such a situation developing. Describing the difficulties FoE perceived in attempting to explain arguments within an alternative worldview to the Commission, the environmental group stated: 'We are concerned about the communication and evaluation problems which are bound to occur when competing claims and recommendations arise from competing paradigms and worldviews. This is a matter of great importance to us because, in section $\mathrm{A}(1)$, our recommendation that the first (organic) option be adopted is based on an emerging ecological worldview that is radically different from the worldview of scientific orthodoxy. ${ }^{81}$

\section{Conclusions}

In recommending an overly favourable outcome for the development of genetic engineering in Aotearoa/New Zealand, the Royal Commission on Genetic Modification expressed preferences contradictory to the majority of the submissions received, as well as to those of broader society. The Commission, widely perceived a priori as a conduit to support the wishes of the public majority, instead effected a disempowerment of this majority. Why was this so? To explore this question, we applied a multi-dimensional framework of discourse analysis to the submission process of the RCGM. This found that the social context of the RCGM was embedded within hegemonic modernist knowledge/power systems and forms of reasoning. These served to contextualise and frame the value positions and points of reference for investigating genetic engineering. The effect was to advantage genetic engineering interests.

To frame its deliberations, the RCGM adopted a submission template design and process determined by the epistemology of modernity-a reductionist philosophical and methodological approach. This disadvantaged holistic approaches, which tend to be adopted by deep or radical environmentalists, or those challenging modernity. This reductionist approach was facilitated by the rules of passage or negotiation of the submission process set by the Commission. These rules constrained the ability of those contesting GM to express their views within their worldviews, and then to have them 
considered according to those frames of reference. Overall, the effect of the discursive process ruled by 'stand alone' conventions enforced the rational/ public: romantic/private discourse split of modernity and preferenced rational answers, particularly those of modern science and industry. Non-science or romantic based concerns about environmental issues of GM tended to be disqualified through compromisation and thus trivialisation of their substance.

Environmental groups were further disadvantaged by the Commission's working document format, which compressed a diverse and intra-contestational range of environmental groups' objections to GE into a generalised summary. This further distorted, compromised and misrepresented the 'rich mosaic' of environmentalist discourses. Another compounding problem was that although the Commission made a concession by recognising the importance of making alternative worldviews visible in the debate, it failed to question its own worldview as both a valid framework for decision-making, and as a defining cause of environmental problems. This further acted to disempower opposition to genetic engineering. The final problem, and perhaps the defining one, was that the Commission proposed a bioethics decision-making process as the best avenue for the resolution of problems concerning GM. This redefined the central issue for GM from being one of outright majority opposition to GM to one of getting the 'right' balance of values and ethics by which to develop GM.

The outcome of New Zealand's Royal Commission on Genetic Modification thus reinforced the social and cultural power of modernist ideals, advantaged genetic engineering interests, disadvantaged environmental groups contesting hegemony, failed to adequately address the serious second modernity risks posed by genetic engineering, and acted to absorb public dissent to genetic engineering. Not only does this highlight that modernity and technoscience culture are recalcitrant to challenge but also that genetic experimentation is set to continue in Aotearoa/New Zealand against the tide of public opinion.

1 The terms 'genetic modification' (GM) and 'genetic engineering' (GE) are used interchangeably in this paper - to mean recombinant-DNA technology.

2 Brian Arnst, personal communication, 2001.

3 See http://indymedia.nelson.org.nz/discuss/msgReader $\$ 78$

4 An overview of these issues is given by R. Hindmarsh and G. Lawrence, 'Bio-utopia: FutureNatural?', in R. Hindmarsh and G. Lawrence (eds), Altered Genes II: The Future?, Melbourne, 2001, chpt. 1. To read about the impacts of biotechnology intellectual property rights on Australian public sector research and other aspects see R. Hindmarsh, 'Consolidating control: plant variety rights, genes and seeds', Australian Journal of Political Economy, vol. 44, 1999, pp.58-78. 


\section{Journal of New Zealand Studies}

5 Many of these groups proposed a GE-free Aotearoa/New Zealand, often stating their preferences for a organic future. In many cases their vision did not exclude GE work in laboratory containment - especially for medical purposes.

6 Newstel news: RNZ 'Focus on Politics' 4 August 2001 cited in [ge]: Greens-RNZ interview re RCGM report, from ge list, 6 August 2001.

7 Annette Cotter, interview, 2001.

8 See Parliament of Australia, Senate Committee 2001, A Cautionary Tale: Fish Don't Lay Tomatoes, A Report on the Gene Technology Bill 2000, Commonwealth of Australia, 2001.

9 A Royal Commission is an independent standing body conducting an inquiry to report to government on matters of public importance, legislation, or government administration. By way of contrast, politicians conduct a parliamentary inquiry. Clearly, the intent of a Royal Commission is to achieve a more even-handed inquiry of the matter at hand.

10 For example, see the website of 'Citizens on the Move for Land and Food without Poisons!', which was a mass grassroots mobilisation against genetic engineering, pesticides and globalisation that occurred in Asia in November 2000. Crowds of 50,000 were not uncommon in this event (see http://www.poptel.org.uk/panap/caravan.htm).

11 See L. Levidow, 'Pollution Metaphors in the UK Biotechnology Controversy', Science as Culture, vol. 9, no. 3, 2000, pp.325-51.

12 The Royal Commission on Genetic Modification, Report of the Royal Commission on Genetic Modification, Wellington, 2001, p.7.

13 See R. Hindmarsh, 'Power Relations, Social-Ecocentrism, \& Genetic Engineering: Agrobiotechnology in the Australian Context', unpublished PhD thesis, Griffith University, Australia, 1994, chpt. 8.

14 For example, see A. Ashforth, 'Reckoning Schemes of Legitimation: On Commissions of Inquiry as Power/Knowledge Forms', Journal of Historical Sociology, vol. 3, no. 1, 1990, pp.1-22; B. Stone, 'Success in Public Inquiries: An Analysis and a Case Study', unpublished paper, Centre for Australian Public Sector Management, Griffith University, 1993.

15 Ashforth, op. cit., p.5.

16 F. Burton and P. Carlen, Official Discourse: On Discourse Analysis, Government Publications, Ideology and the State, London, 1979, p.8, cited in ibid., pp.2-3.

17 R. Hindmarsh, 'Power Relations'.

18 Cited in Yahoo Australia \& NZ News, 'Royal Commission offers a way forward', (http:// au.dailynews.yahoo.com/headlines/20010730/nrbusiness/996477614-134823959.html), 30 July 2001.

19 A. Polson, 'Greenpeace should read the Royal Commission report', Media Release 133/01, Federated Farmers of New Zealand (Inc), 28 August 2001.

20 P. Routledge, 'The Third Space of Critical Engagement', Antipode, vol. 28, no. 4, 1996, pp.399-419.

21 Advocating a certain theoretical position and then developing a methodological approach that emanates from that theoretical position is engaging in what Brett refers to as the 'freedom of the social scientist to hold any opinions he [sic] chooses . . ' (E. Brett, Colonialism and Underdevelopment in East Africa, London, 1973, p.8). Similarly, Latour's point is appropriate for any formulation of methodological approach, 'No amount of method can make one text less of a fiction than another one. In consequence, we are perfectly free to use any style, any data, any effect, any composition that we (the authors of a written text) deem adapted to the audience' (B. Latour, 'Will the last person to leave the social studies of science please turn on the tape-recorder?', 1986, pp.541-48, p.548; cited in S. Shapin (ed), 'Following scientists around', Essay Review, Social Studies of Science, vol. 18, 1988, pp.533-50, p.547). Brett (p.9) argued that every 


\section{New Zealand's Royal Commission on Genetic Modification}

social scientist as a member of society is "concerned ultimately with some notion of the "public interest", which is identified with that of particular groups or strata in society, and ... [the social scientist will] derive his [sic] evaluative assumptions from theirs. Adam Smith spoke for the rising bourgeoisie, Marx for the proletariat; many developmentalists accept the objectives and perspectives of the new political and technological élites . . . All this suggests that our models of society must ultimately have prescriptive and hence political implications. They are to be seen as arguments in favour of particular courses of action based upon assumptions about the ultimate nature of human needs and empirical observation of the effects of past actions upon subsequent situations.'

22 A. Naess, Ecology, Lifestyle and Community: Outline of an Ecosophy, translated and edited by D. Rothenberg, Cambridge, 1990, p.131.

23 P. Couchman and K. Fink-Jensen, Public Attitudes to Genetic Engineering in New Zealand, DSIR Crop Research Report, 1990, No. 138.

24 Royal Commission on Genetic Modification, 'Members of RCGM', http://www. gmCommission.govt.nz/contact/bios.html, 30 August 2001.

25 Royal Commission on Genetic Modification 'Introduction', Warrant, English Version http://www.gmCommission.govt.nz/intro/warrant_eng.html, 7 March, 2001.

26 Ibid.

27 F. Capra, The Web of Life: A New Synthesis of Mind and Matter, London, 1997.

28 U. Beck, Risk Society, London, 1992.

29 See C. Merchant, Radical Ecology, London, 1992; also Capra op. cit.

30 L. Benton and J. Short, Environmental Discourse and Practice, Oxford, 1999, p.1.

31 N. Fairclough, Discourse and Social Change, Cambridge, 1992.

32 Ibid. See also S. Hill, The Tragedy of Technology, London, 1988.

33 See Shapin, op. cit., p.534

34 An example of disempowerment of an agency was where the Environmental Defenders Office (EDO) of New South Wales, a community legal centre that specialises in public interest environmental law, was denied a grant of legal aid by the Legal Aid Commission as of 1 January 1993. Prior to that date, the EDO relied on grants of legal aid for a substantial part of its funding to run environmental protection cases. Behind the loss of funding was the New South Wales state government, which failed in September 1992 to provide the Legal Aid Commission with the $\$ 3.2$ million which had been allocated as a result of a Commonwealth State funding agreement. The EDO has fought several court cases, one of which involved the Forestry Commission; the cases were funded by legal aid. The viability of the EDO is now placed at risk, and an avenue for people concerned about enforcing environmental protection laws has been seriously undermined (Anon, 'Government stamps on legal aid for environmental protection laws', Environs, April/May 1993, p.9). An example of empowerment was where environmental protesters from the North East Forest Alliance (NEFA) who were concerned with the logging of old growth rainforests at Killiekrankie, Oates State Forest, in northern New South Wales in 1992, undertook their own environmental impact statements (EISs) of catchment areas, under the legislative guidance of the Soils Erosion Mitigation Commission (which oversees the laws pertaining to soil erosion into water catchment areas). These EISs and support, or social alignment, from the grass-roots movement empowered the Environmental Protection Agency (EPA) to take the Forestry Commission to court in early 1993 over some 90,000 tonnes of soil that washed into the Bellinger River as a result of breaches of logging practices by the Commission (Bellinger Forest Action Group, pers comm., April 1993).

35 V. Shiva, Staying Alive, London, 1989.

36 Merchant, op. cit. 


\section{Journal of New Zealand Studies}

37 Reductionism refers to the concept that a complex system can be abstracted and comprehended through the isolation and analysis of an aspect of that system (see Capra, op. cit.).

38 A. Feenberg, Alternative Modernity: The Technical Turn in Philosophy and Social Theory, California, 1995.

39 S. Restivo, 'The Theory Landscape in Science Studies: Sociological Traditions', in S. Jasonoff (ed), Handbook of Science and Technology Studies, California, 1995, pp. $95-110$.

40 S. Harding, 'Thinking Science, Thinking Society', Social Text, vols. 46/47, nos. 1\&2, 1996, p.15.

41 V. Shiva, op. cit.; see also T. Rogers-Hayden and J. R Campbell, forthcoming.

42 M. Coutinho, 'Ecological metaphors and environmental rhetoric: An analysis of The Ecologist and Our Common Future', Environment and History, vol. 3, 1997, pp.177-95, p.187.

43 S. Cozzens and E. Woodhouse, 'Science, Government, and the Politics of Knowledge', in S. Jasonoff (ed), Handbook of Science and Technology Studies, London, 1995, pp.533-53.

44 Interestingly, in the findings of an Australian survey of public attitudes to genetic engineering - funded by the Department of Industry, Science and Technology - it was noted as significant that those who questioned the 'scientific world view' were more against, than in favour of, genetic engineering (see J. Kelly, Public Perceptions of Genetic Engineering: Australia, 1994, Final Report to the Department of Industry, Science and Technology, Canberra, 1995).

45 References to Cartesian dualism refer to the work of French philosopher and mathematician René Descartes. His scholarship was based on the metaphorical separation of the body and mind, and the parallel abstraction of nature from complexity through reduction (see note 43).

46 S. Yearley, 'Social Movements and Environmental Change', in M. Redclift and T. Benton (eds), Social Theory and the Global Environmental, New York, 1994, pp.150-68.

47 R. Grove-White and B. Szerszynski, 'Getting Beyond Environmental Ethics', Environmental Values, vol. 1, 1991, pp.285-96.

48 R. Grove-White, 'Environmentalism: A New Moral Discourse for Technological Society?' in K. Milton (ed), Environmentalism, London, 1993, pp.18-30.

49 R. Hindmarsh, 'Constructing Bio-utopia: Laying Foundations Amidst Dissent', in R. Hindmarsh and G. Lawrence (eds), Altered Genes II: The Future?, Melbourne, 2001; see also R. Grove-White, 'Environmental Knowledge and Public Policy Needs: On Humanising the Research Agenda', in S. Lash, B. Szerszynski and B. Wynne (eds), Risk, Environment and Modernity, London, 1996, p.269-85.

50 Hindmarsh, 'Constructing Bio-utopia'.

51 P. Loge, 'Language is a Virus: Discourse and the Politics and Public Policy of Biotechnology', paper prepared for the 12th International Meeting of the Society of Environmental Toxicology and Chemistry, Seattle, WA, 6 November, 1991, p.13.

52 Ibid., pp.14-15.

53 Ibid., pp.10-11.

54 M. Hobbs, 'Questions and Answers', Royal Commission into GM, Ministry for the Environment, http://www.mfe.govt.nz/new/q\&a.htm, 7 October 2001.

55 E. Yoxen, The Gene Business: Who Should Control Biotechnology?, New York, 1983, p.15.

56 See J. van Dijck, Imagenation: Popular Images of Genetics, London, 1998.

57 Ibid.; Hindmarsh and Lawrence, 'Bio-utopia'.

58 Levidow, op. cit. 


\section{New Zealand's Royal Commission on Genetic Modification}

59 Grove-White, 'Environmental Knowledge'.

60 Available on http://www.gmCommission.govt.nz.

61 Royal Commission on Genetic Modification 'Inquiry Activities', Appendix B Guidelines for the Presentation of Submissions for 'Interested Persons', http://www.gmCommission.govt.nz/inquiry/appendix_b.html, 7 March, 2001.

62 See Manufacturing Consent [video recording], Montreal, Quebec: Necessary Illusions/ National Film Board of Canada, 1992.

63 Green Party of Aotearoa/New Zealand, Submission to the Royal Commission on Genetic Modification, 2000, p.2.

64 Berylla, interview, 2001.

65 RCGM, Report of the Royal Commission on Genetic Modification, Appendix 2, Wellington, 2001, p.15.

66 Ibid., p.19.

67 Ibid., p.18.

68 Benton and Short, op. cit.

69 RCGM, Appendix 2, p.11.

70 E. Alexander, 'After Rationality, What?' Journal of the American Planning Association, vol. 50, no. 1, 1984, pp.62-69.

71 The other six core values were: the uniqueness of Aotearoa/New Zealand; the uniqueness of our cultural heritage; being part of a global family; the well-being of all; freedom of choice; and participation.

72 Aventis CropScience, Submission to the Royal Commission on Genetic Modification, 2000, pp.1-2.

73 Ibid., p.8.

74 See Loge, op. cit.

75 Nelson GE-Free Awareness Group, Submission to the Royal Commission on Genetic Modification, 2000, p.23.

76 Ibid., p.7.

77 RCGM, Report, p.25.

78 See T. O'Riordan and J. Jordan, 'The Precautionary Principle in Contemporary Environmental Politics', Environmental Values, vol. 4, 1995, pp.191-2.

79 Coutinho, op. cit.

80 RCGM, Report, p.27, emphasis added.

81 FoE, Submission to the Royal Commission on Genetic Modification, 2000, pp.23-24. 